\title{
THE ROSE STEM GIRDLER (Agrilus aurichalceus Redtenbacher) (Insecta: Coleoptera: Buprestidae), A NEW THREAT TO PRAIRIE ROSES
}

DAVID J. LARSON, Department of Biology, Memorial University of Newfoundland, St. John's, NF A1B 3X9. Email: dlarson@mun.ca. (Saskatchewan address: Box 56, Maple Creek., SK S0N1N0.dmlarson@Sasktel.net)

Since the summer of 1999 there has been a noticeable reduction in the wild rose (mainly Rosa acicularis Lindl. and $R$. woodsii Lindl. but also larger canes of $R$. arkansana Porter) bushes in the Maple Creek region of southwestern Saskatchewan. In 2000, some of the larger rose canes within stands were dead or died over the summer but such mortality did not seem unusual. However, in 2001 large areas of dead canes occurred in many stands and this expanded in 2002 so that entire stands were either dead or their leaves reddened prematurely in August and the stems died by early September. In 2000 I did not pay much attention to the dead stems other than to note that some of the dense patches seemed less impenetrable than they had been previously. However the significant increase in mortality in 2001 prompted me to examine the stems more carefully. On examination, it was found that almost every dead stem, somewhere along its length, had evidence of a spiral engraving under the bark in the surficial layer of the sapwood. These engravings were usually along the thicker parts of the stem from ground level to about mid-length with usually one spiral engraving per stem but some stems had several. The engravings were certainly the tunnels of an insect but the causative agent was not found and it could not be determined if the tunnel occurred before or after stem death.

In 2002, in an effort to determine what insect was tunneling in the stem, I examined rose bushes over the growing season for signs of damage and presence of possible causative insects, sweeping roses with a beating net to collect insects from the plants, and I also examined the bark and stripped the bark from stems that seemed moribund or showed leaf discoloration. Examination of the plants for insects and beating yielded a collection of typical insects associated with roses but also several specimens of a buprestid beetle (Agrilus sp.) were collected between midJune and mid-July. Canes showing premature reddening and/or wilting of leaves were noted from late July into late August. Each of these canes had an insect larva tunneling under the bark and engraving the outer portion of the sapwood (Fig. 1). The tunnels were characteristic, following a helical path and forming several tight circles that effectively girdled the cane and presumably killed it as leaf discoloration and wilting occurred distal to the tunnel. The larvae removed from the tunnels were characteristic buprestid beetle larvae and presumably the larvae of the Agrilus species collected as adults from the foliage. The boring pattern was similar to that noted on dead canes the previous year. The beetle larvae were apparently tunneling in live canes and were the cause of the cane's death.

No native prairie species of Agrilus is known to feed on roses. However, Bright recorded A. aurichalceus Redtenbacher (the rose stem girdler) as occurring in Canada in southern Ontario and Quebec and in the 


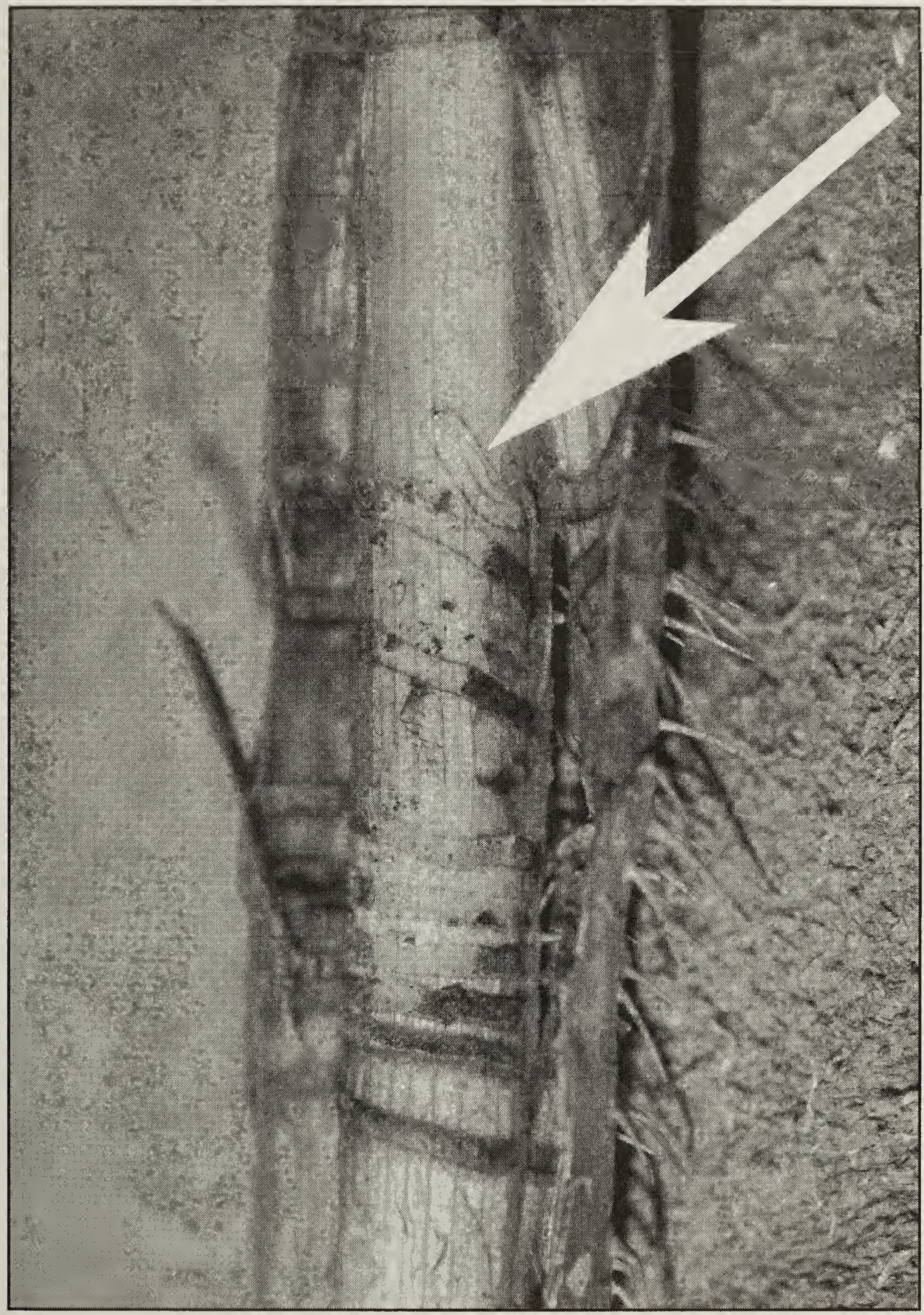

Fig. 1. Rose cane with bark removed to show spiral tunnel pattern of rose stem girdler (Agrilus aurichalceus) larva. The arrow points to a fully grown larva at the end of its tunnel. David J. Larson 
eastern United States west to Colorado.' The Saskatchewan specimens fit this species in both larval habits and adult morphology. This species is not native to North America but was introduced into New Jersey in 1923 and has subsequently increased its range in the eastern part of the continent, now to also include the southern part of the prairie provinces. Apparently it has recently spread into southwestern Saskatchewan.

The rose stem girdler is an economically important species known to kill roses as well as attacking species of Ribes (current) and Rubus (raspberry and blackberry). According to Bright, the female beetle lays its eggs into the bark of the cane, usually near the base of a leaf.' The larva bores into the sapwood and turns upwards as well as spiraling around the cane several times thus cutting the phloem and killing the cane. The mature larva bores into the pith of the cane, where it overwinters, then pupates the following spring with the adult beetle emerging in early summer. Although the larval burrows were easily found in Saskatchewan canes, I have not seen the overwintering or pupal tunnels in the pith and it is possible that, as an adaptation to the cold Saskatchewan winter, the larva might be leaving the cane and overwintering in the soil. There is one generation a year.

This beetle has the potential of greatly modifying the vegetational landscape of parts of the prairies. Roses form an important part of patches of bushes. Their dense, prickly stems exclude or reduce livestock grazing inside the patches and therefore they protect other plant species and maintain dense vegetation tangles that form important habitat for various types of wildlife. With the death of the roses, the patches become more open and easily accessible to both grazing animals and predators and the net result may be both opening up of such bush patches and possibly their loss. It is unlikely roses will be threatened as they persist as root stock and the beetle does not attack small canes, only canes of two or three years of age. As one rancher told me, "something strange is happening to the roses, they are blooming closer to the ground each year", an observation related to the fact the older and taller canes have died off and flowers are now produced only on the younger, shorter canes. It is likely that the prairies will end up with roses that are shorter and form patches with less dense, smaller stems.

\section{Acknowledgements.}

These observations were made while conducting research on insects of grassland pools, supported by a Natural Sciences and Engineering Research Council of Canada Discovery Grant. This note is offered as a contribution to the Grasslands Insect Project of the Biological Survey of Canada (Terrestrial Arthropods).

1. BRIGHT, D. E. 1987. The insects and arachnids of Canada, Part 15. The metallic wood-boring beetles of Canada and Alaska. Coleoptera: Buprestidae. Research Branch, Agriculture Canada, Publication 1810. 335 pp.

\begin{abstract}
"The rose represents love, magic, hope, and the mystery of life itself. Its name, ordinary enough, refers to its color (rosa is Latin for 'red'). But that's like saying the heart is a muscle situated on the left side of the rib cage. The flower's mysterious associations date to the earliest civilizations-the Persian word for rose, gul, also meant 'flower' and was close to ghul, the word for "spirit.""
\end{abstract}

